\title{
An experimental and numerical investigation on the influence of External \\ Gas Recirculation on the HCCI auto-ignition process in an engine: thermal, diluting and chemical effects
}

\author{
Hatim Machrafi*a, $^{\text {a, }}$, Simeon Cavadias ${ }^{\mathrm{a}, \mathrm{b}}$, Philippe Guibert ${ }^{\mathrm{b}}$ \\ ${ }^{a}$ UPMC Université Paris 06, LGPPTS, Ecole Nationale Supérieure de Chimie de Paris, France

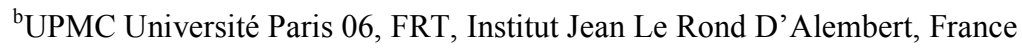

UPMC Université Paris 06, LGPPTS, Ecole Nationale Supérieure de Chimie de Paris, 11, rue de Pierre et Marie Curie, 75005 Paris, France

This article is a full length article

*corresponding author:

11, rue de Pierre et Marie Curie, 75005 Paris, France

Tel.: +33144276718

Fax: +33143265813

E-mail address: hatim-machrafi@enscp.fr 


\section{Abstract}

In order to contribute to the solution of controlling the auto-ignition in a Homogeneous Charge Compression Ignition (HCCI) engine, parameters linked to External Gas Recirculation (EGR) seem to be of particular interest. Experiments performed with EGR present some difficulties in interpreting results using only the diluting and thermal aspect of EGR. Lately, the chemical aspect of EGR is taken more into consideration, because this aspect causes a complex interaction with the dilution and thermal aspects of EGR. This paper studies the influence of EGR on the auto-ignition process and particularly the chemical aspect of EGR. The diluents present in EGR are simulated by $\mathrm{N}_{2}$ and $\mathrm{CO}_{2}$, with dilution factors going from 0 to $46 \mathrm{vol} \%$. For the chemically active species that could be present in EGR, the species CO, $\mathrm{NO}$ and $\mathrm{CH}_{2} \mathrm{O}$ are used. The initial concentration in the inlet mixture of $\mathrm{CO}$ and $\mathrm{NO}$ is varied between 0 and $170 \mathrm{ppm}$, while that of $\mathrm{CH}_{2} \mathrm{O}$ alters between 0 and $1400 \mathrm{ppm}$. For the investigation of the effect of the chemical species on the auto-ignition, a fixed dilution factor of $23 \mathrm{vol} \%$ and a fixed EGR temperature of $70{ }^{\circ} \mathrm{C}$ are maintained. The inlet temperature is held at $70{ }^{\circ} \mathrm{C}$, the equivalence ratios between 0.29 and 0.41 and the compression ratio at 10.2 . The fuels used for the auto-ignition are n-heptane and PRF40. It appeared that CO, in the investigated domain, did not influence the ignition delays, while NO had two different effects. At concentrations up until $45 \mathrm{ppm}$, NO advanced the ignition delays for the PRF40 and at higher concentrations, the ignition delayed. The influence of NO on the auto-ignition of nheptane seemed to be insignificant, probably due to the higher burn rate of n-heptane. $\mathrm{CH}_{2} \mathrm{O}$ seemed to delay the ignition. The results suggested that especially the formation of $\mathrm{OH}$ radicals or their consumption by the chemical additives determine how the reactivity of the auto-ignition changed. 
Key words: auto-ignition control, HCCI engine, chemical additives, dilution, External Gas Recirculation, carbon monoxide, nitrogen oxide, formaldehyde

\section{Introduction}

The combustion mode HCCI has gained much interest as a new technology to reduce the pollution of automotive engines. The difficulty of controlling the auto-ignition is one of the most important aspects that obstruct the implementation of this mode of combustion. Much experimental and numerical research has been performed analyzing several HCCI combustion mechanisms [1-7]. A certain HCCI engine that turns properly would need a certain fuel, inlet temperature, equivalence ratio and compression ratio, which are chosen to meet power-, emission- and efficiency optimums. It is then more likely that a certain optimum would be chosen, which could be found by a detailed study on the effect of such parameters on the auto-ignition process. However, in order to control efficiently the auto-ignition process and more particularly the moment of auto-ignition, another parameter seems to be more interesting for the auto-ignition analysis. This parameter is called Exhaust Gas Re-circulation (EGR). The effect of EGR has been investigated in both Diesel and HCCI engines $[\mathbf{1 , 2 , 5 , 8 -}$ 12]. The effect of EGR can be used and changed constantly whenever needed. Therefore it enjoys much attention, being promising to solve the problem of the auto-ignition control. Efforts have been made to interpret the results of the influence of EGR on the auto-ignition process, stating that the effect of EGR on HCCI combustion can be divided into three parts: a dilution effect (inert gasses present in the EGR), a thermal effect (heat exchange, thermal loss to the wall, EGR ratio mixture quality, EGR temperature, heat capacity) and a chemical effect $[1,2,8-12]$. Especially the chemical effect has gained much interest, leading to investigations about the effect of adding chemically active species to an inlet mixture in an engine [13-16]. The chemical effect influences not only the overall kinetics, but it also can change a specific 
reaction path, which makes this effect particularly interesting for the investigation of the autoignition process.

This paper aims at investigating the effect of the chemical aspect of EGR on the auto-ignition process in an HCCI engine. The fuels n-heptane and PRF40 are used for this investigation. PRF40 stands for a Primary Reference Fuel, containing 40 vol\% iso-octane and 60 vol\% nheptane. The compression ratio is kept at 10.2, whilst the equivalence ratios are varied between 0.32 and 0.41 . The inlet temperature is kept at $70{ }^{\circ} \mathrm{C}$. The experimental results are backed-up with the same validated surrogate mechanism that has been used in previous work [17]. The 0 D HCCI engine module in the Chemkin code is used for the calculations with this mechanism. The same engine properties and initial parameters are used as in the experiments, which are discussed in section 2. For the chemical species $\mathrm{CO}, \mathrm{NO}$ and $\mathrm{CH}_{2} \mathrm{O}$ are chosen. The species $\mathrm{CO}$ is issued from incomplete combustion, $\mathrm{NO}$ from high temperatures during combustion, while formaldehyde is formed between the cool flame and the final ignition. The objective is to study the effect of some different chemical groups, which can be present in EGR, on the auto-ignition process.

\section{Experimental set-up of the EGR installation}

A schematic representation of the experimental set-up is shown in figure 1. The complete experimental set-up comprises an HCCI engine itself, the air inlet system, the fuel injection system, a pre-mixture tank for inlet mixture homogeneity and the EGR installation. The HCCI engine has a compression ratio of 10.2 , a bore of $82.55 \mathrm{~mm}$, a stroke of $114.5 \mathrm{~mm}$ and a displacement volume of $612 \mathrm{~cm}^{3}$. The ratio of the connecting rod to crank radius is 4.44 . The exhaust valve opens at $140{ }^{\circ}$ After Top Dead Center (ATDC) and closes at $15^{\circ}$ ATDC. The intake valve opens at $10^{\circ} \mathrm{ATDC}$ and closes at $146^{\circ} \mathrm{BTDC}$. Three tanks are available in the 
installation: a stabilisation tank, an EGR mixture tank and a pre-mixture tank. The stabilisation tank serves for the stabilisation of the impulses of the flow of the intake air, caused by the motion of the engine's piston. In the EGR mixture tank, the different constituents of the EGR, of which the flow is regulated by a flow meter, are mixed to compose the EGR mixture. The idea is to simulate experimentally the three most important effects of EGR (diluting effect, thermal effect and chemical effect). Either nitrogen or carbon dioxide (the major diluting species in EGR) is chosen for the diluting compounds. The thermal effect can be simulated by heating/cooling the EGR flow or by choosing different diluting compounds with different heat capacities. For the chemical effect, the species CO, NO or formaldehyde can be chosen, which are one of the most important minor species present in EGR that contribute to toxic pollution. An investigation of the diluting effect is performed in order to choose the optimal amount of dilution for the interpretation of the effect of the chemical species on the auto-ignition. The influence of the EGR temperature is similar to that of the inlet temperature, which has been studied in former work [18] and is well known in the literature, except that different volumetric EGR flows can strengthen or weaken the influence. Therefore the EGR temperature is kept constant and equal to the inlet temperature. The EGR ratio is defined as the EGR mass flow divided by the total intake mass flow, that is: $\mathrm{m}_{\mathrm{EGR}} /\left(\mathrm{m}_{\mathrm{EGR}}+\mathrm{m}_{\text {air }}\right)$. The EGR ratio can be varied from 0 to about $50 \%$. The sensors that are connected to the installation are the temperature sensors for the cooling water (which is set to be $50{ }^{\circ} \mathrm{C}$ ), for the intake air, for the EGR and for the exhaust gasses. The temperature of the intake air, the EGR and the lubricating oil (set at $40{ }^{\circ} \mathrm{C}$ ) are regulated by a PID regulator. The pre-mixture tank serves to mix the fuel with the entering air and EGR flow. Before the fuel/air/EGR mixture enters the engine, it is passed through a tube of which the geometry (several $90^{0}$ bends) enhances the homogeneity of the mixture. 
The measurements of the equivalence ratio, measured by the flow rates of the fuel and the air, present an error of $+/-0.005$, while the compression ratio shows an error of $+/-0.5$. The temperatures of the cooling water and the oil as well as that at the inlet of the engine show an error of $+/-1{ }^{\circ} \mathrm{C}$. The composition of the fuel has an error of $+/-1 \mathrm{vol} \%$, while that of the EGR flow exhibits an error of $+/-2 \%$. The EGR consists of three parts: the thermal effect shows an error on the EGR temperature of $+/-1{ }^{\circ} \mathrm{C}$, the dilution effect shows the same error as the EGR flow (+/- $2 \%)$ and finally the flow of the chemical species $\left(\mathrm{CO}, \mathrm{NO}\right.$ and $\left.\mathrm{CH}_{2} \mathrm{O}\right)$ show an error of $+/-5 \%$. The error of the output values are expressed in the standard deviation, using the following formula:

$\sigma=\sqrt{\frac{1}{N-1} \sum_{i=1}^{N}\left(y_{i}-\hat{y}\right)^{2}}$

In this formula, $\mathrm{N}$ is the number of experiments (at the same conditions) that are performed, $y_{i}$ one of the values of the results, $\hat{y}$ the mean value and $\sigma$ the standard deviation. The cylinder pressure measured in this work by the pressure sensor is a mean pressure taken out of 50 cycles. The pressure measurement exhibits a standard deviation of the maximum pressure of around $0.12 \%$ for a motored pressure, but this error can go up to about $1.5-2 \%$ at combustion and $3 \%$ for unstable combustion.

The heat release, $d Q_{\text {release }} / \mathrm{d} \theta$ is obtained from a combination of the First Law of Thermodynamics and an energy balance over the cylinder, resulting into:

$\frac{d Q_{\text {release }}}{d \theta}=\frac{d Q_{\text {wall }}}{d \theta}+\frac{\gamma}{\gamma-1} P \frac{d V}{d \theta}+\frac{1}{\gamma-1} V \frac{d P}{d \theta}$

Here, $\theta$ is the crank angle degree, while $\mathrm{dQ}_{\text {wall }} / \mathrm{d} \theta$ is the heat loss to the wall. The volume, $\mathrm{V}$, is determined from the engine geometry and $\gamma$ is the isentropic constant $\left(\mathrm{C}_{\mathrm{p}} / \mathrm{C}_{\mathrm{v}}\right)$. The heat loss is calculated at each point in time according to:

$Q_{\text {wall }}=h A\left(T-T_{\text {wall }}\right)$ 
In this equation, $\mathrm{h}$ represents the overall heat transfer coefficient through the wall and $\mathrm{A}$ the heat transfer surface of the cylinder. The temperature $\mathrm{T}$ is estimated by using the gas temperature, calculated from the ideal gas law. The wall temperature $T_{\text {wall }}$ is estimated by measuring the heat loss to the cooling water. A for HCCI application adjusted heat transfer coefficient is used, proposed by [19], calibrating the scaling factor, $\alpha_{\text {scaling: }}$

$h_{\text {global }}=\alpha_{\text {scaling }}\left(\frac{V(\theta)}{0,25 \pi D^{2}}\right)^{-0,2} P^{0,8} T^{-0,73} w^{0,8}$

with

$w=\left(C_{11}+C_{12} \frac{\pi D \omega_{c}}{\overline{S_{p}}}\right) \overline{S_{p}}+\frac{C_{2}}{6} \frac{V_{d} T_{i}}{P_{i} V_{i}}\left(P-P_{\text {motored }}\right)$

$V(\theta)$ is the engine volume as function of the crank angle degrees, D is the engine's bore, $P$ the pressure, $\mathrm{T}$ the temperature and $\mathrm{w}$ the average cylinder gas velocity. The term after the scaling factor in equation 4 represents the instantaneous chamber height. $S_{p}$ represents the mean piston speed, $\omega_{\mathrm{c}}$ the angular crank shaft velocity in $\mathrm{rad} / \mathrm{s}, \mathrm{V}_{\mathrm{d}}$ the displacement volume, $\mathrm{P}$ the pressure at combustion, $P_{\text {motored }}$ the motored pressure while $T_{i}, V_{i}$ and $P_{i}$ represent respectively the temperature, volume and pressure at inlet valve closing. In equation 5 , the constants $C$ have taken the next values: $\mathrm{C}_{11}=2.28, \mathrm{C}_{12}=0.308$ and $\mathrm{C}_{2}=0.324 \mathrm{~cm} / \mathrm{Ks}$. Furthermore, for the use of the reduced kinetic model as explanation of the experimental findings, an estimation of the residual gas fraction and temperature has been performed in order to estimate more realistically the temperature at inlet valve closing. More detail about the heat transfer, the estimation of the wall temperature and the estimation of the residual gas fraction and temperature, according to the experimental configuration of this paper, can be found in previous work [18]. The heat release maximums showed a confidence interval of $+/-10 \%$ and the ignition delays of $+/-0.5 \mathrm{CAD}$. 
The air contains a certain amount of water vapour. The addition of $\mathrm{H}_{2} \mathrm{O}$ to the fuel/air mixture would reduce the cylinder temperature after combustion initiation, having a stronger effect than $\mathrm{N}_{2}$ but weaker than $\mathrm{CO}_{2}$, since $\mathrm{H}_{2} \mathrm{O}$ has a heat capacity between that of $\mathrm{N}_{2}$ and $\mathrm{CO}_{2}$. Ladommatos et al. [11] investigated the effects of water vapour on the ignition delay of diesel fuel in a diesel engine. They found that an addition of water vapour resulted into a slight increase of the ignition delay. According to them, the water vapour seems, next to diluting the fuel/air mixture, to form dissociation products at high compression temperatures, which enhances the ignition process with respect to carbon dioxide. Nonetheless, the overall effect of water vapour seems [11] to increase and not decrease the ignition delay. To exclude as much as possible the effect of water vapour on the auto-ignition process, a hygroscopic absorber is placed in the air circuit right after a dust filter.

\section{The global effects of $\mathrm{CO}$, $\mathrm{NO}$ and $\mathrm{CH}_{2} \mathrm{O}$ on the auto-ignition}

The HCCI chemistry of PRF fuels is well known in the literature and can be consulted in [2025]. The effect of $\mathrm{CO}$ on the auto-ignition process is not quite clear in the literature and sometimes even contradictory. The effect of the addition of $\mathrm{CO}$ to n-butane and iso-butane entering a port-fuel injected spark-ignition engine has been investigated by Sung et al. [14]. The addition of $\mathrm{CO}$ did not have any effects, with the exception that over the pressure ranges of 1 to $5 \mathrm{~atm}$ the addition of $\mathrm{CO}$ resulted into a relatively small increase of the laminar flame speed, while at elevated pressures ( $>5 \mathrm{~atm}$ ) and fuel-lean conditions the opposite was observed. At pressures higher than $5 \mathrm{~atm}$ and at fuel-lean conditions (which are for the major part the conditions of an HCCI engine), $\mathrm{CO}$ decreased the laminar flame speed. A contradicting observation was made by Subramanian et al. [7]. In their work they compared three different kinetic mechanisms in order to find out the influence of $\mathrm{CO}$ addition on the auto-ignition delay of mixtures dedicated to HCCI engines. The fuel that was considered is n- 
heptane and the calculations were performed at constant pressure. Two out of the three mechanisms did not show any influence of $\mathrm{CO}$ addition, while one of them showed an advancing ignition delay at a temperature of $600 \mathrm{~K}$, an equivalence ratio of 0.7 and a pressure of 20 bar. At the same conditions, but for an equivalence ratio of 1.0, the two mechanisms that did not show an effect, now, presented a delay in the ignition when adding $\mathrm{CO}$ to the inlet mixture. Increasing the temperature to $1000 \mathrm{~K}$ showed an advancing ignition delay on adding $\mathrm{CO}$, for all the three mechanisms. This shows that the effect of $\mathrm{CO}$ is not quite clear and more research is needed. Since this species is available in the exhaust, using EGR necessitates the understanding of the effect of $\mathrm{CO}$.

Much research is performed in the field of the interaction of NO with hydrocarbons. Examples in the field of interaction of nitrogen oxides with hydrocarbons are kinetics of nitrogen chemistry in combustion [26,27], kinetics of nitrous oxide decomposition [28], hydrogen cyanide oxidation in a flow reactor [29] and a study of HNCO oxidation chemistry [30]. Other works concerning the modelling of thermal $\operatorname{deNO}_{\mathrm{x}}[31]$ and reburning [32] are performed as well. The effect of the addition of $\mathrm{NO}_{2}$ to propane-oxygen-nitrogen mixtures has been studied by Pinard et al. [15] in a $4.70 \mathrm{~m}$ steel detonation tube with a $0.145 \mathrm{~m}$ internal diameter. Pinard et al. measured the deflagration-to-detonation distance in this tube and found that the addition of $\mathrm{NO}_{2}$ caused no change in this distance, indicating that the kinetic changes brought about by the $\mathrm{NO}_{2}$ are not significant to the initiation of detonation. Faravelli et al. [3] show that the addition of NO to hydrocarbons at low temperatures enhances ignition. This enhancement, however, becomes an inhibition at higher amounts of NO addition. Faravelli et al. [3] found also that at high temperatures the addition of NO loses its enhancing capabilities (above $\sim 1000 \mathrm{~K}$ it becomes less effective and above $\sim 1400 \mathrm{~K}$ it disappears) because the alkyl radicals decompose and become of less importance. 
The aldehyde that play the most important role during the cool flame seems to be formaldehyde, though not much work is done on the influence of aldehydes on the HCCI auto-ignition process $[\mathbf{4 , 3 3 - 3 6 ]}$. Furutani et al. [4] show that the addition of formaldehyde to a HCCI natural-gas engine enhanced the ignition by promoting the preflame reaction of the main natural gas fuel. Yamaya et al. [33] examined the effect of formaldehyde addition using a single cylinder diesel engine and different fuel/air mixtures (the fuel being methane, ethane, propane and/or n-butane). Depending on the fuel type in the mixture and temperature to which mixtures are compressed, the effect of formaldehyde is found to be either suppressing or promoting for the ignition. The effect is suppressing for fuels that naturally show an early cool flame ignition tendency (a two stage combustion) and promoting for fuels that naturally show no cool flame tendencies (a one stage combustion). Salooja [34] states that all aldehydes except formaldehyde generally promote combustion, acetaldehyde being the most effective promotor. The same was observed by Moore and Tipper [35] in a flow system. Yamada et al. [36] performed experiments in a single-cylinder, side-valve type four-stroke engine, modified for HCCI operation. They found that addition of formaldehyde caused chain termination, retarding the final ignition. Not much research is performed regarding the effect of aldehydes on the auto-ignition process. This paper intends to investigate this effect. Aldehydes are formed in the intermediate temperature stage, right after the initiation of the cool flame. The hydroperoxides (as $\mathrm{C}_{7} \mathrm{H}_{14} \mathrm{OOH}$ ) that are formed in the low temperature stage, decompose in the intermediate temperature stage forming, amongst others, aldehydes, $\mathrm{OH}$ and alkenes [3739]. 


\section{Results and discussion}

\subsection{The thermal and diluting effects on the auto-ignition process}

In order to analyse the effects of the species $\mathrm{CO}, \mathrm{NO}$ and $\mathrm{CH}_{2} \mathrm{O}$ on the auto-ignition process with sufficient precision and control, the extent of dilution should be chosen. The principal diluents in EGR are $\mathrm{N}_{2}$ and $\mathrm{CO}_{2}$. It appeared that a dilution factor of $23 \mathrm{vol} \%$ was needed. The dilution factor is based on keeping the mass entering the cylinder constant and is calculated with respect to nitrogen, since the flow meters are calibrated with respect to nitrogen. The fuel/air mass rate is kept constant for a certain equivalence ratio. The dilution factor for a certain species $\mathrm{x}$ (present in EGR) is defined as follows:

$D_{x}=\frac{\sum_{x} \rho_{x} \dot{V}_{x}}{\sum_{x} \rho_{x} \dot{V}_{x}+\rho_{N 2} \dot{V}_{\text {fuel / air }}}$

In this equation $\rho_{\mathrm{x}}$ is the density of species $\mathrm{x}, \rho_{\mathrm{N} 2}$ is the density of nitrogen, $\dot{V}_{\text {fuel /air }}$ represents the volumetric flow of the fuel/air mixture with a certain fixed equivalence ratio and $\dot{V}_{x}$ is the volumetric flow of the species $\mathrm{x}$. If only one species is present in EGR, such as nitrogen, the dilution factor reduces itself to:

$D_{N 2}=\frac{\dot{V}_{N 2}}{\dot{V}_{N 2}+\dot{V}_{\text {fuel / air }}}$

In the case $\mathrm{CO}_{2}$ is used as the diluent in EGR, the dilution factor becomes:

$D_{\mathrm{CO} 2}=\frac{\rho_{\mathrm{CO} 2} \dot{V}_{\mathrm{CO} 2}}{\rho_{\mathrm{CO} 2} \dot{V}_{\mathrm{CO} 2}+\rho_{\mathrm{N} 2} \dot{V}_{\text {fuel / air }}}$

If one wants to compare the effect of the type of diluent, the dilution factor should be the same, in order to have the same mass and load entering the cylinder. This means that if $\mathrm{CO}_{2}$ is used as a diluent instead of $\mathrm{N}_{2}$, it follows that $\mathrm{D}_{\mathrm{CO} 2}=\mathrm{D}_{\mathrm{N} 2}$. For instance, a measured $\mathrm{N}_{2}$ flow and fuel/air flow of respectively $36 \mathrm{l} / \mathrm{min}$ and $120 \mathrm{l} / \mathrm{min}$, results into a dilution factor of 23 
vol\%. For the same dilution factor the measured $\mathrm{CO}_{2}$ flow should be $\dot{V}_{\mathrm{CO} 2}=\frac{\rho_{\mathrm{N} 2} \dot{V}_{N 2}}{\rho_{\mathrm{CO} 2}}=22.7$ $1 / \min \mathrm{CO}_{2}$.

A higher dilution factor, by increasing the EGR flow at constant fuel/air flow, would allow higher addition concentrations for the chemical species. However, a higher dilution would also cause a lower heat release, lower indicated efficiencies and eventually incomplete combustion, which should be avoided. The type of diluent can also influence the heat release, by changing the heat capacity of the gas mixture in the cylinder. This thermal effect that is caused by the heat capacity of the diluent should not influence the study of the chemical effects on the auto-ignition process. In order to find out the limits of dilution and thermal effects, the effect of dilution by $\mathrm{N}_{2}$ and $\mathrm{CO}_{2}$ (having a higher heat capacity) on the ignition delays is presented in figure 2. Figure 2 shows that the cool flames and the final ignitions are delayed when diluting by nitrogen. Addition of nitrogen to the inlet mixture, basically diluting the mixture, lowers the overall concentration of the reacting species, resulting into a higher ignition delay. Dilution mostly entails also a difference in heat capacity. However, nitrogen having only a slightly lower $\left(29.1 \mathrm{~J} /(\right.$ mole $\mathrm{K})$, at $\left.25^{\circ} \mathrm{C}\right)$ heat capacity than air $(29.2 \mathrm{~J} /($ mole $\mathrm{K})$, at $25^{\circ} \mathrm{C}$ ) and largely present in air, hardly changes the heat capacity of the gas entering the cylinder. So the changing heat capacity plays a minor role in this case. It seems, however, that the effect of carbon dioxide is stronger. Since the mass for both the diluents is the same at the same dilution factor, the reduction in $\mathrm{O}_{2}$ mass concentration is the same. Therefore, the difference can be explained by the higher heat capacity of $\mathrm{CO}_{2}\left(37 \mathrm{~J} /(\right.$ mole $\mathrm{K})$, at $\left.25^{\circ} \mathrm{C}\right)$ than nitrogen. It increases thus more the heat capacity of the entire charge when it is mixed with the air/fuel mixture. So $\mathrm{CO}_{2}$ slows down the cylinder temperature uprising during the compression process more than nitrogen does. The ignition timing is therefore more delayed. Using $\mathrm{CO}_{2}$ as the diluent can lower too much the overall kinetics rendering the investigation on the effects of the chemical species on the auto-ignition process limited. Therefore and in 
order to avoid as much as possible the thermal effects caused by the diluents, $\mathrm{N}_{2}$ is chosen as the diluting agent in EGR. Figure 3 shows the effect of $\mathrm{N}_{2}$ on the heat release distribution (represented by the ratio of the heat release at the final ignition to the heat release at the cool flame, $A_{f} / A_{c}$ ). It seems, from figure 3, that the dilution factor has a rather insignificant influence on the distribution of the heat release. This suggests that the study on the effect of the chemical species on the heat release distribution would be valid for dilution factors from 0 to $46 \mathrm{vol} \%$ at the conditions of this investigation. However, figure 4 shows that the effect of the dilution factor influences considerably the total heat releases as would be expected. In order to study the effect of the chemical species on the auto-ignition process, the dilution factor should not be increased much more and a value of $23 \mathrm{vol} \%$ is chosen.

\subsection{The effect of $\mathrm{CO}$ on the auto-ignition process}

The experiments that were performed in this work for $\mathrm{CO}$ showed that at the added concentrations (up to a possible maximum of $170 \mathrm{ppm}$ ), CO did not show any significant influence on the cool flame delays, the final ignition delays, the pressure nor the heat release.

$\mathrm{CO}$ is formed in, among others, the following reactions [40]:

$\mathrm{RCHO}+\mathrm{X} \bullet=\mathrm{RCO} \bullet+\mathrm{XH}$

$\mathrm{RCO} \bullet+\mathrm{M}=\mathrm{R} \bullet+\mathrm{CO}+\mathrm{M}$

$\mathrm{HCO} \bullet+\mathrm{M}=\mathrm{H} \bullet+\mathrm{CO}+\mathrm{M}$

$\mathrm{HCO} \bullet+\mathrm{O} 2=\mathrm{CO}+\mathrm{HO}_{2}^{\bullet}$

These are the reactions that take place amongst those that take place right after the cool flame. The $\mathrm{CO}$ interaction with the auto-ignition process is then considered by the following reactions in the case of an engine [41, p. 593]:

$\mathrm{CO}+\mathrm{OH} \bullet=\mathrm{CO}_{2}+\mathrm{H} \bullet$

$\mathrm{H} \bullet+\mathrm{O}_{2}+\mathrm{M}=\mathrm{HO}_{2} \bullet+\mathrm{M}$ 
Following these reactions, an addition of $\mathrm{CO}$ would consume more $\mathrm{OH}$ radicals, replacing them by the less reactive $\mathrm{HO}_{2}$ radicals, leaving less for the consummation of the fuel, thus delaying the final ignition. In this work, confirmed partially by the work of Sung et al. [14] and Subramanian et al. [7], CO does not have any effect. The reason could well be that the addition concentration is not high enough in order to observe any difference. Sung et al. [14] observed a decreased laminar speed (overall reactivity) at pressures higher than 5 atm (higher concentrations). In an engine, a higher overall reactivity would be expressed by a decreasing ignition delay. Using the surrogate mechanism, higher concentrations of $\mathrm{CO}$ addition are implemented and the effect on the auto-ignition delays is simulated. The results, at an inlet temperature of $70{ }^{\circ} \mathrm{C}$, an equivalence ratio of 0.3 and compression ratio of 10.2 , are presented in figure 5 for the fuel n-heptane. Figure 5 shows that at an addition of $1000 \mathrm{ppm}$ of $\mathrm{CO}$ the onset of the pressure increase at the final ignition changes. No significant change is noted for an addition of $\mathrm{CO}$ of $100 \mathrm{ppm}$. This latter is in the range that is investigated in the experiments (up to $170 \mathrm{ppm}$ ) and at that range the experimental and numerical findings are similar. The change is clear at an addition of $10,000 \mathrm{ppm}$. These calculations show clearly that the addition of $\mathrm{CO}$ delays the ignition and thus decreases the overall reactivity as is one of the observations found in the literature [7,15]. It is worth mentioning, though, that a concentration of $10,000 \mathrm{ppm}$ of $\mathrm{CO}$ in the inlet of an engine is less likely to occur.

However, the reaction where $\mathrm{CO}$ consumes $\mathrm{OH}$ radicals, forming thereby $\mathrm{CO}_{2}$, is a highly exothermic reaction, providing much of the heat release during the final ignition. So, when more $\mathrm{CO}$ is added to the fuel/air mixture, the heat release at the final ignition increases. This increase should be expressed by an increase in the peak pressure. The contribution of the added $\mathrm{CO}$ to the heat release depends on the quantity. Figure 5 shows that the peak pressure does not increase until 10,000 ppm of $\mathrm{CO}$ is added. Knowing that for an equivalence ratio of 0.3 , the amount of fuel that is added neighbours 2 mass $\%$ of the total fuel/air mixture and that 
$170 \mathrm{ppm}$ of $\mathrm{CO}$ equals about $0.02 \mathrm{mass} \%$ of the fuel/air mixture, it can therefore be said that for an addition of $170 \mathrm{ppm}$ of $\mathrm{CO}$, the chemical energy that is added by $\mathrm{CO}$ is insignificant. However, 10,000 ppm of $\mathrm{CO}$ equals about $1 \mathrm{mass} \%$. This represents the same order of magnitude as for the fuel. In this case the chemical energy would count, as figure 5 indeed shows. However, for HCCI engine operating conditions, $\mathrm{CO}$ addition values of more than $10^{3}$ ppm would be less likely to occur. According to the surrogate mechanism and the operating conditions of this investigation, the chemical energy would then not influence significantly the auto-ignition process.

\subsection{The effect of NO on the auto-ignition process}

The NO experiments were performed with an EGR ratio of $23 \mathrm{vol} \%$ as is explained in section 4.1. Figure 6 shows the influence of the addition of NO on the auto-ignition delays for a PRF40. Figure 6 shows that the cool flame and final ignition delays seem to be advanced at first instance by addition of NO, with a maximum effect at an addition of $45 \mathrm{ppm}$. The cool flame is less affected. However, beyond an addition of $45 \mathrm{ppm}$, the promoting role of NO seems to be overtaken by an inhibiting role, since the ignition delays increase. This suggests that there is a competition between a promoting and inhibiting role of NO. Faravelli et al. [3] explain the effect of the addition of NO to hydrocarbons on the ignition delay. NO has the ability to activate peroxy radicals in:

$\mathrm{RO}_{2}+\mathrm{NO}=\mathrm{RO}+\mathrm{NO}_{2}$

Here, $\mathrm{R}$ can be either $\mathrm{H}$ or an alkyl group. The transformation, however, of $\mathrm{HO}_{2}$ to $\mathrm{OH}$ is responsible for over $80 \%$ of the conversion of $\mathrm{NO}$ to $\mathrm{NO}_{2}$, with the peroxy radicals $\mathrm{ROO}$ playing only a minor role:

$\mathrm{HO}_{2}+\mathrm{NO}=\mathrm{OH}+\mathrm{NO}_{2}$ 
$\mathrm{NO}$ is furthermore formed, at least partially, by $\mathrm{NO}_{2}+\mathrm{H}=\mathrm{NO}+\mathrm{OH}$ which is a much faster reaction than the one before, so that $\mathrm{NO}_{2}$ is depleted in the system. Adding up these two reactions gives $\mathrm{HO}_{2}+\mathrm{H}=2 \mathrm{OH}$, which is more reactive than the recombination reaction $\mathrm{HO}_{2}$ $+\mathrm{H}=\mathrm{H}_{2} \mathrm{O}_{2}$ that would otherwise have taken place with no addition of NO. So the addition of $\mathrm{NO}$ enhances the ignition delay by producing eventually more $\mathrm{OH}$ radicals that consume the fuel $[3,42]$. However, excessive amounts of NO inhibit the oxidation at low and intermediate temperatures, because of the scavenging of $\mathrm{OH}$ radicals by the reactions [9-11]:

$\mathrm{NO}+\mathrm{OH}+[\mathrm{M}]=\mathrm{HONO}+[\mathrm{M}]$

$\mathrm{HONO}+\mathrm{OH}=\mathrm{NO}_{2}+\mathrm{H}_{2} \mathrm{O}$

These reactions add up to:

$\mathrm{NO}+2 \mathrm{OH}=\mathrm{NO}_{2}+\mathrm{H}_{2} \mathrm{O}$

The scavenging of reactive $\mathrm{OH}$ radicals is increased by $\mathrm{NO}_{2}+\mathrm{HO}_{2}=\mathrm{HONO}+\mathrm{O}_{2}$. The competition of this reaction with $\mathrm{HO}_{2}+\mathrm{NO}=\mathrm{OH}+\mathrm{NO}_{2}$ provides the first inhibiting effect, while the subsequent reaction of $\mathrm{HONO}$ with an $\mathrm{OH}$ radical to form $\mathrm{NO}_{2}$ and $\mathrm{H}_{2} \mathrm{O}$ is the second. When the $[\mathrm{NO}]$ is such that the ratio of the reaction rates of "NO $+\mathrm{OH}$ " and "fuel + OH" becomes slightly greater than one, the system's reactivity drops sharply and the NO addition becomes an inhibition. Furthermore it seems that due to the lesser importance of peroxy radicals at higher temperatures, because they decompose, the enhancing effect of NO becomes less important and even disappears at higher temperatures, $1400 \mathrm{~K}[\mathbf{3 , 4 2}]$.

The effect of NO is not necessarily the same on every fuel. For PRF40, the effect was visible in figure 6 and is confirmed clearly by the heat release curves in figure 7. For n-heptane, though, the effect is less important, illustrated by figure 8 . Figure 8 shows the effect of the addition of $\mathrm{NO}$ on the heat release curves at the same conditions as figure 6 . From figure 8 , it can be seen that at different NO additions, the onset of the pressure rise at the final ignition 
does not differ more than $1 \mathrm{CAD}$ from one another. Considering a confidence interval of 0.5 CAD, these results can not clearly show that NO influences the auto-ignition of n-heptane at these conditions. It seems that the influence of NO on the auto-ignition of n-heptane is quite different than its influence on the auto-ignition of PRF40. Probably, n-heptane creates already that much $\mathrm{OH}$ radicals by itself that the production of $\mathrm{OH}$ by the addition of $\mathrm{NO}$ does not add an observable amount of $\mathrm{OH}$. PRF40, however, creates less OH radicals, so that the addition of $\mathrm{NO}$ increases significantly the amount of $\mathrm{OH}$ radicals. This explanation is provided from the numerical results in figure 9, obtained from an experimentally validated combined surrogate-NO mechanism (table 1), which has been validated experimentally for HCCI engine applications, concerning the interaction of NO with PRF fuels [18]. In figure 9, the normalized $\mathrm{OH}$ concentrations are calculated at the cool flame for a compression ratio of 10.2, an inlet temperature of $70^{\circ} \mathrm{C}$ and an equivalence ratio of 0.35 . Figure 9 shows indeed that for n-heptane, addition of $\mathrm{NO}$ does not change significantly the $\mathrm{OH}$ concentration, while for the PRF40 the change is clearly visible. From figure 7, it appears that when the final ignition delay increases, the heat release at the final ignition decreases. This means that very small amounts of NO not only influence significantly the ignition delays but can also alter considerably the heat release and therefore the power output of the engine.

The heat release ratio of the final ignition to the cool flame is presented in figure 10, regarding the fuel "60 vol\% n-heptane and $40 \mathrm{vol} \%$ iso-octane". The total heat release as a function of the addition of $\mathrm{NO}$, with respect to no $\mathrm{NO}$ addition, is presented in figure 11 . Figure 10 shows that, for both equivalence ratios 0.32 and 0.41 , the heat release ratio is at its maximum when the final ignition is at its minimum. The latter corresponds to the highest reactivity, which is observed for an $\mathrm{NO}$ addition of $45 \mathrm{ppm}$. The same trend is observed for the total heat release in figure 11. Summarizing the results from figures 10 and 11 , it can be seen that a higher reactivity favours the heat release towards the final ignition (since both the 
total heat release and its ratio become higher). In other words, when NO plays a promoting role, more heat and thus power are released at the final ignition at the expense of the cool flame. This favours the efficiency of an engine and makes NO interesting for the control of the auto-ignition process in an HCCI engine. This effect is stronger at a lower equivalence ratio. At higher equivalence ratios, there is more fuel which produces more $\mathrm{OH}$ radicals. The increase of $\mathrm{OH}$ radicals due to an addition of $\mathrm{NO}$ is then less significant.

Figures 7 and 8 and the analysis made from figures 10 and 11 show another interesting feature. Though the addition of NO increases the amount of $\mathrm{OH}$ radicals for the fuel PRF40 (figure 9), it does not seem to affect significantly the amount of heat release at the cool flame. This suggests that the $\mathrm{OH}$ radicals, which are formed due to the addition of $\mathrm{NO}$, influence in a greater extent the reactivity at the final ignition. In order to investigate the extent of the influence of $\mathrm{NO}$ on the reactivity at the final ignition, the combined surrogate-NO model, mentioned earlier in the text, is used for this purpose. Three initial concentrations of NO are used, 0, 50 and $300 \mathrm{ppm}$. These calculations are performed at an inlet temperature of $70{ }^{\circ} \mathrm{C}$, an equivalence ratio of 0.6 , a compression ratio of 14 and a dilution factor of $14 \mathrm{vol} \%$. In order to generalize this analysis to real fuels, a surrogate of gasoline is used as fuel, comprising $11 \mathrm{vol} \% \mathrm{n}$-heptane, $59 \mathrm{vol} \%$ iso-octane and $30 \mathrm{vol} \%$ toluene. Since this surrogate gasoline is more resistant to auto-ignition (higher octane rating) than the fuel PRF40, the dilution factor had to be lowered from $23 \mathrm{vol} \%$ to $14 \mathrm{vol} \%$. To assess the reactivity of the fuel, these examples are focused on the reaction of iso-octane and some of its intermediary products (like iso-butene and propene) with the $\mathrm{OH}$ radicals. The results of the numerical calculations are presented in table 2 in the form of the maximum reaction rates of each of these three reactions for each NO addition. The reference is taken to be $0 \mathrm{ppm}$ NO addition. Table 2 shows that for all the three reactions, the reaction rates of respectively iso-octane, isobutene and propene with $\mathrm{OH}$ increase at an addition of $50 \mathrm{ppm} \mathrm{NO}$ by 28 to $65 \%$. At an 
addition of $300 \mathrm{ppm} \mathrm{NO}$, the reaction rate of iso-octane with $\mathrm{OH}$ decreases by $40 \%$, while the reaction rates of respectively iso-butene and propene with $\mathrm{OH}$ decrease by a factor $10^{2}$. These results show clearly that the addition of NO has a considerable influence on the reactivity, which first increases on adding $50 \mathrm{ppm}$ of $\mathrm{NO}$ and then decreases on adding $300 \mathrm{ppm}$ of NO. This confirms the promoting and inhibiting role of NO, depending on the quantity added.

\subsection{Effect of the aldehydes on the auto-ignition delays}

Figure 12 presents the influence of the addition of formaldehyde $\left(\mathrm{CH}_{2} \mathrm{O}\right)$ on the auto-ignition delays. Formaldehyde seems to affect the ignition delays quite clearly. Formaldehyde can react with a hydroxide radical forming $\mathrm{CHO}$ and water. $\mathrm{CHO}$ then reacts with oxygen forming CO. The overall reaction is then:

$\mathrm{CH}_{2} \mathrm{O}+\mathrm{OH}+\mathrm{O}_{2}=>\mathrm{H}_{2} \mathrm{O}+\mathrm{HO}_{2}+\mathrm{CO}$

So, formaldehyde shares $\mathrm{OH}$ with the fuel, so that less $\mathrm{OH}$ is left for the fuel, producing instead the less reactive radical $\mathrm{HO}_{2}$. This decreases the overall reactivity and delays the ignition. Figure 12 also shows that the effect of formaldehyde addition at higher equivalence ratios is stronger. Since, at higher equivalence ratios more $\mathrm{OH}$ radicals are formed, the effect of formaldehyde addition on the auto-ignition delays is stronger at higher equivalence ratios. At the cool flame, less $\mathrm{OH}$ radicals are formed than at the final ignition and the temperatures are lower as well. Therefore, the effect of formaldehyde is weaker at the cool flame than it is at the final ignition. Figure 13 presents a simulation, made with the surrogate mechanism, which shows that adding formaldehyde to a fuel/air mixture results into a lower $\mathrm{OH}$ concentration at the cool flame. Even until the final ignition the $\mathrm{OH}$ concentration stays lower for a higher formaldehyde addition. The reduction of the amount of $\mathrm{OH}$ radicals that are left for the fuel has its consequences on the power output of the engine. This can be illustrated by the total heat release and by the heat release ratio over the final ignition and the cool flame, 
presented respectively in figures 14 and 15 , with respect to no formaldehyde addition. Figure 14 shows that the addition of formaldehyde to the inlet mixture decreases the total heat release but not more than $6 \%$ at an addition of $1400 \mathrm{ppmv}$ of $\mathrm{CH}_{2} \mathrm{O}$. It seems from figure 15 , that the heat release at the final ignition decreases with respect to the heat release at the cool flame on adding more formaldehyde. So, formaldehyde affects considerably more the final ignition than it affects the cool flame, which has been observed for the ignition delays as well. This holds for both the presented equivalence ratios.

\section{Conclusions}

The diluting effect of EGR, represented by $\mathrm{N}_{2}$ and $\mathrm{CO}_{2}$, has been studied. The thermal effect has been treated by the difference of heat capacity of these two diluents. In order to avoid the thermal effect, $\mathrm{CO}_{2}$ is not used as a diluent for the chemical species, but instead $\mathrm{N}_{2}$ is used, having a heat capacity close to that of air. Moreover, the EGR temperature is set equal to the inlet temperature. In order to be able to vary the concentrations of the chemical species sufficiently, without diluting too much, the dilution factor is chosen to be $23 \mathrm{vol} \%$. The effect of three chemical species on the auto-ignition process has been investigated, namely $\mathrm{CO}, \mathrm{NO}$ and $\mathrm{CH}_{2} \mathrm{O}$.

The studied effect of $\mathrm{CO}$ on the auto-ignition process in this paper shows both differences and agreements with the literature. The opposite views, regarding the effect of $\mathrm{CO}$ on the autoignition, suggest that, depending on the thermodynamical conditions, $\mathrm{CO}$ can either promote or inhibit the auto-ignition delay. The results of this paper showed that experimentally up to an addition of $170 \mathrm{ppm}$ of $\mathrm{CO}$, no effect was observed. The numerical results using the surrogate mechanism showed the same results. The surrogate mechanism showed that at $\mathrm{CO}$ additions of $1000 \mathrm{ppm}$ and more, $\mathrm{CO}$ delayed the auto-ignition. At a $\mathrm{CO}$ addition of 10,000 
ppm, the chemical energy supplied by $\mathrm{CO}$ begins to play an important role, increasing thereby the peak pressure.

The effect of NO on the auto-ignition process has shown two different aspects: NO can both promote and inhibit the ignition delays, depending on the added concentration. Only very small amounts of NO seem to influence significantly the auto-ignition process. Even the heat release distribution and the total heat release are influenced by only $45 \mathrm{ppm}$ addition of NO, which makes this species particularly interesting. The results could imply that NO can increase the burn rate. At higher equivalence ratios or with fuels having a higher burn rate, the effect of NO is less pronounced. At these conditions, the surrogate mechanism explains that there are already enough $\mathrm{OH}$ radicals in the reacting mixture, so that the increase of $\mathrm{OH}$ radicals due to NO addition is relatively insignificant. The addition of NO is not efficient at high temperatures. However, for engine conditions, especially at lean, low-temperature HCCI conditions, this problem is not significant and the use of NO for auto-ignition control in HCCI engines is rather promising.

The effect of formaldehyde seems to delay the auto-ignition. The explanation is that the $\mathrm{OH}$ radicals are shared by formaldehyde with the fuel. This has a negative impact on the heat release at the final ignition as well as on the total heat release. The decreased reactivity decreases the auto-ignition delays.

It can be concluded that, generally, the effect of the chemical additives played a very important role in influencing the amount of $\mathrm{OH}$ radicals that are present in the system. This seemed to be determining whether the auto-ignition was delayed (less $\mathrm{OH}$ radicals give a decreased overall reactivity) or advanced (more $\mathrm{OH}$ radicals give an increased overall reactivity). 


\section{References}

1 R. Chen, N. Milovanovic, Intern. J. Therm. Sc., 41 (2002) 805-813.

2 H. Zhao, Z. Peng, J. Williams, N. Ladommatos, Understanding the effects of recycled burnt gases on the controlled autoignition (CAI) combustion in four-stroke engines, SAE International, International Fall Fuels and Lubricants Meeting and Exposition, 2001, 2001-01-3607.

3 T. Faravelli, A. Frassoldati, E. Ranzi, Combust. Flame, 132 (2003) 188-207.

4 M. Furutani, M. Kono, M. Kojima, M. Nose, Y. Ohta, Chemcal species histories up to ignition in premixed-compression-ignition natural-gas engine, The fifth International Symposium on Diagnostics and Modeling of Combustion in Internal Combustion Engines, Comodia 2001, p. 461.

5 A. Babajimopoulos, G.A. Lavoie, D.A. Assanis, Modeling HCCI combustion with high levels of residual gas fraction - A comparison of two VVA strategies, 2003, SAE 2003-01-3220.

6 D. Law, D. Kemp, J. Allen, G. Kirkpatrick, T. Copland, Controlled Combustion in an IC-Engine with a Fully Variable Valve Train, 2001, SAE 2000-01-0251.

7 P. Risberg, D. Johansson, J. Andrae, G.T. Kalghatgi, P. Bjornbom, H.E. Engstrom, The Influence of NO on the Combustion Phasing in an HCCI Engine, SAE Technical Papers, 2006, 2006-01-0416.

8 D.L. Mitchell, J.A. Pinson, T.A. Litzinger, The effects of simulated EGR via intake air dilution on combustion in an optically accessible DI diesel engine, SAE International, Fuels \& Lubricants Meeting \& Exhibition, 1993, SAE-932798.

9 N. Ladommatos, S.M. Abdelhalim, H. Zhao, Z. Hu, The dilution, chemical, and thermal effects of exhaust gas recirculation on diesel engine emissions - Part 1: effect 
of reducing inlet charge oxygen, SAE International, International Spring Fuels and Lubricants Meeting, 1996, SAE-961165.

10 N. Ladommatos, S.M. Abdelhalim, H. Zhao, Z. Hu, The dilution, chemical, and thermal effects of exhaust gas recirculation on diesel engine emissions - Part 2: effects of carbon dioxide, SAE International, International Spring Fuels and Lubricants Meeting, 1996, SAE-961167.

11 N. Ladommatos, S.M. Abdelhalim, H. Zhao, Z. Hu, The dilution, chemical, and thermal effects of exhaust gas recirculation on diesel engine emissions - Part 3: effects of water vapour, SAE International, International Spring Fuels and Lubricants Meeting, 1997, SAE-971659.

12 N. Ladommatos, S.M. Abdelhalim, H. Zhao, Z. Hu, The dilution, chemical, and thermal effects of exhaust gas recirculation on diesel engine emissions - Part 4: effects of carbon dioxide and water vapour, SAE International, International Spring Fuels and Lubricants Meeting, 1997, SAE-971660.

13 M. Senthil Kumar, A. Ramesh, B. Nagalingam, Intern. J. Hydr. Ener., 28 (2002) $1143-$ 1154.

14 C.J. Sung, Y. Huang, J.A. Eng, Combust. Flame, 126 (2001) 1699-1713.

15 P.F. Pinard, A.J. Higgins, J.H.S. Lee, Combust. Flame, 136 (2003) 146-154.

16 R.G. Papagiannakis, D.T. Hountalas, Appl. Therm. Eng., 23 (2003) 353-365.

17 H. Machrafi, S. Cavadias, J. Amouroux, The development and experimental validation of a reduced ternary kinetic mechanism for the auto-ignition at HCCI conditions, proposing a global reaction path for ternary gasoline surrogates, Combust. Flame, submitted March 2008.

18 H. Machrafi, Development and experimental validation of kinetic schemes for hydrocarbon mixtures for HCCI applications. Investigation of the auto-ignition 
process and the application to internal combustion engines, $\mathrm{PhD}$ thesis of the University of Paris 6 (UPMC), Paris, 2007.

19 J. Chang, O. Güralp, Z. Filipi, D. Assanis, T.-W. Kuo, P. Najt, R. Rask, New Heat Transfer Correlation for an HCCI Engine Derived from Measurements of Instantaneous Heat Flux, 2004, SAE 2004-01-2996.

20 J. Warnatz, Proc. Combust. Inst. 24 (1992) 553-579.

21 H.J. Curran, W.J. Pitz, C.K. Westbrook, C.V. Callahan, F.L. Dryer, Proc. Combust. Inst. 27 (1998) 379-387.

22 A. Ciajolo, A. D'Anna, Combust. Flame, 112 (1998) 617-622.

23 H.J. Curran, P. Gaffuri, W.J. Pitz, C.K. Westbrook, Combust. Flame, 114 (1998) 149177.

24 R. Minetti, M. Carlier, M. Ribaucour, E. Therssen, L.R. Sochet, Combust. Flame, 102 (1995) 298-309.

25 E. Ranzi, T. Faravelli, P. Gaffuri, A. Sogaro, A. D'anna, A. Ciajolo, Combust. Flame, 108 (1997) 24-42.

26 J.A. Eng-Jr, W.R. Leppard, P.M. Najt, F. Dryer, The Interaction Between Nitric Oxide and Hydrocarbon Oxidation Chemistry in a Spark-Ignition Engine, International Fuels \& Lubricants Meeting \& Exposition, 1997, SAE 972889.

27 J.A. Miller, C.T. Bowman, Prog. Ener. Combust. Sci., 15 (1989) 287-338 .

28 P. Glarborg, J.E. Johnsson, K. Dam-Johansen, Combust. Flame, 99 (1994) 523-532.

29 P. Glarborg, J.A. Miller, Combust. Flame, 99 (1994) 475-483.

30 P. Glarborg, P.G. Kirstensen, S.H. Jensen, K. Dam-Johansen, Combust. Flame, 98 (1994) 241-258.

31 P. Glarborg, K. Dam-Johansen, J.A. Miller, R.J. Kee, M.E. Coltrin, Intern. J. Chem. Kin., 26 (1994) 421-436. 
32 P. Kilpinen, P. Glarborg, M. Hupa, Industr. \& Eng. Chem. Res., 31 (1992) 1477-1490.

33 Y. Yamaya, M. Furutani, Y. Ohta, International Symposium on Diagnostics and Modeling of Combustion in Internal Combustion Engines, 6 (2004) 199-206.

34 K.C. Salooja, Combust. Flame, 9 (1965) 373-382.

35 F. Moore, C.F.H. Tipper, Combust. Flame, 19 (1972) 81-87.

36 H. Yamada, K. Suzaki, H. Sakanashi, N. Choi, A. Tezaki, Combust. Flame, 140 (2005) 24-33.

37 I. Glassman, Combustion, Academic Press, 3rd ed., San Diego, 1996.

38 W. Leppard, A Comparison of Olefin and Paraffin Autoignition Chemistries: A Motored-Engine Study, 1989, SAE-892081.

39 E. Ranzi, A. Sogaro, P. Gaffuri, G. Pennati, C. K. Westbrook, W. J. Pitz, Combust. Flame, 99 (1994) 201-211.

40 C.T. Bowman, Prog. Ener. Combust.Sc., 1 (1975) 33-45.

41 J.B. Heywood, Fundamentals of Internal combustion, McGrawHill, 1988, p.593.

42 A. Frassoldati, T. Faravelli, E. Ranzi, Combust. Flame, 135 (2003) 97-112. 
Table

Table 1: Reduced chemical kinetic reaction scheme representing surrogates of n-heptane, iso-

octane and toluene and the interaction of $\mathrm{NO}$ with the surrogates

\begin{tabular}{|c|c|c|c|c|}
\hline \multicolumn{5}{|c|}{$\mathrm{k}=\mathrm{A} \mathrm{T}^{\mathrm{b}} \exp \left(-\mathrm{E}_{\mathrm{a}} / \mathrm{RT}\right)$} \\
\hline $\begin{array}{c}\text { Reaction } \\
\text { number }\end{array}$ & Reaction & $\begin{array}{c}\mathrm{A} \\
\text { [mole-cm-s-K] }\end{array}$ & $\mathrm{b}[-]$ & Ea $[\mathrm{J} / \mathrm{mole}]$ \\
\hline Reactions & N-heptane initiation reactions & & & \\
\hline 1 & $\mathrm{C} 7 \mathrm{H} 16+\mathrm{O} 2=>\mathrm{C} 7 \mathrm{H} 15-2+\mathrm{HO} 2$ & $2,80 \mathrm{E}+14$ & 0 & 197212,4 \\
\hline 2 & $\mathrm{C} 7 \mathrm{H} 16+\mathrm{OH}=>\mathrm{C} 7 \mathrm{H} 15-2+\mathrm{H} 2 \mathrm{O}$ & $4,80 \mathrm{E}+09$ & 1,3 & 2886,29 \\
\hline 3 & $\mathrm{C} 7 \mathrm{H} 16+\mathrm{HO} 2=>\mathrm{C} 7 \mathrm{H} 15-2+\mathrm{H} 2 \mathrm{O} 2$ & $1,00 \mathrm{E}+13$ & 0 & 70851 \\
\hline 4 & $\mathrm{C} 7 \mathrm{H} 15-2+\mathrm{O} 2=\mathrm{C} 7 \mathrm{H} 15 \mathrm{O} 2$ & $2,00 \mathrm{E}+12$ & 0 & 0 \\
\hline 5 & $\mathrm{C} 7 \mathrm{H} 15 \mathrm{O} 2=\mathrm{C} 7 \mathrm{H} 14 \mathrm{O} 2 \mathrm{H}$ & $6,00 \mathrm{E}+11$ & 0 & 85188,4 \\
\hline 6 & $\mathrm{C} 7 \mathrm{H} 14 \mathrm{O} 2 \mathrm{H}+\mathrm{O} 2=\mathrm{C} 7 \mathrm{H} 14 \mathrm{O} 2 \mathrm{HO} 2$ & $2,34 \mathrm{E}+11$ & 0 & 0 \\
\hline 7 & C7H14O2HO2=>C7KET21+OH & $2,97 \mathrm{E}+13$ & 0 & 111606 \\
\hline 8 & C7KET21=>C5H11+CO+CH2O+OH & $1,00 \mathrm{E}+16$ & 0 & 177232 \\
\hline 9 & $\mathrm{C} 5 \mathrm{H} 11=>\mathrm{C} 2 \mathrm{H} 5+\mathrm{C} 3 \mathrm{H} 6$ & $3,20 \mathrm{E}+13$ & 0 & 118294 \\
\hline 10 & $\mathrm{C} 3 \mathrm{H} 6+\mathrm{OH}=>\mathrm{CH} 3 \mathrm{CHO}+\mathrm{CH} 3$ & $3,50 \mathrm{E}+11$ & 0 & 0 \\
\hline Reactions & Iso-octane initiation reactions & & & \\
\hline 11 & $\mathrm{IC} 8 \mathrm{H} 18+\mathrm{O} 2+\mathrm{O} 2=>\mathrm{R} 2 \mathrm{C} 8 \mathrm{H} 17 \mathrm{OO}+\mathrm{HO} 2$ & $2,10 \mathrm{E}+17$ & 0 & 204820 \\
\hline 12 & $\mathrm{IC} 8 \mathrm{H} 18+\mathrm{OH}=>\mathrm{CC} 8 \mathrm{H} 17+\mathrm{H} 2 \mathrm{O}$ & $2,48 \mathrm{E}+13$ & 0 & 1839,2 \\
\hline 13 & $\mathrm{IC} 8 \mathrm{H} 18+\mathrm{HO} 2=\mathrm{CC} 8 \mathrm{H} 17+\mathrm{H} 2 \mathrm{O} 2$ & $2,02 \mathrm{E}+12$ & 0 & 60192 \\
\hline 14 & $\mathrm{CC} 8 \mathrm{H} 17+\mathrm{O} 2=\mathrm{R} 2 \mathrm{C} 8 \mathrm{H} 17 \mathrm{OO}$ & $2,50 \mathrm{E}+19$ & $-2,5$ & 0 \\
\hline & Reverse reaction & $1,79 \mathrm{E}+13$ & 0 & 103747,6 \\
\hline 15 & $\mathrm{R} 2 \mathrm{C} 8 \mathrm{H} 17 \mathrm{OO}=\mathrm{C} 8 \mathrm{H} 16 \mathrm{OOH}$ & $3,28 \mathrm{E}+12$ & 0 & 119130 \\
\hline & Reverse reaction & $1,80 \mathrm{E}+11$ & 0 & 84018 \\
\hline 16 & $\mathrm{C} 8 \mathrm{H} 16 \mathrm{OOH}+\mathrm{O} 2=\mathrm{R} 2 \mathrm{C} 8 \mathrm{H} 16 \mathrm{OOHOO}$ & $3,52 \mathrm{E}+19$ & $-2,5$ & 0 \\
\hline & Reverse reaction & $7,00 \mathrm{E}+12$ & 0 & 91040,4 \\
\hline 17 & $\mathrm{R} 2 \mathrm{C} 8 \mathrm{H} 16 \mathrm{OOHOO}=>\mathrm{OH}+\mathrm{C} 7 \mathrm{H} 14 \mathrm{CHO}(\mathrm{OOH})$ & $4,80 \mathrm{E}+12$ & 0 & 119130 \\
\hline 18 & $\mathrm{C} 7 \mathrm{H} 14 \mathrm{CHO}(\mathrm{OOH})=>\mathrm{CO}+\mathrm{IC} 6 \mathrm{H} 13+\mathrm{CH} 2 \mathrm{O}+\mathrm{OH}$ & $2,05 \mathrm{E}+15$ & 0 & 173052 \\
\hline 19 & $\mathrm{CC} 8 \mathrm{H} 17+\mathrm{HO} 2=>1 \mathrm{C} 6 \mathrm{H} 13+\mathrm{C} 2 \mathrm{H} 3+\mathrm{H} 2 \mathrm{O} 2$ & $2,00 \mathrm{E}+12$ & 0 & 0 \\
\hline 20 & $\mathrm{CC} 8 \mathrm{H} 17=>\mathrm{IC} 4 \mathrm{H} 8+\mathrm{IC} 4 \mathrm{H} 9$ & $4,28 \mathrm{E}+12$ & 0 & 115368 \\
\hline 21 & $\mathrm{IC} 6 \mathrm{H} 13=>\mathrm{IC} 3 \mathrm{H} 7+\mathrm{C} 3 \mathrm{H} 6$ & $2,51 \mathrm{E}+13$ & 0 & 117876 \\
\hline 22 & $\mathrm{IC} 4 \mathrm{H} 9+\mathrm{O} 2=>\mathrm{IC} 4 \mathrm{H} 8+\mathrm{HO} 2$ & $1,00 \mathrm{E}+12$ & 0 & 20900 \\
\hline 23 & $\mathrm{IC} 4 \mathrm{H} 8+\mathrm{OH}=>\mathrm{IC} 3 \mathrm{H} 7+\mathrm{CH} 2 \mathrm{O}$ & $1,51 \mathrm{E}+12$ & 0 & 0 \\
\hline 24 & $\mathrm{IC} 3 \mathrm{H} 7+\mathrm{O} 2=>\mathrm{C} 3 \mathrm{H} 6+\mathrm{HO} 2$ & $1,00 \mathrm{E}+12$ & 0 & 20900 \\
\hline 25 & $\mathrm{C} 3 \mathrm{H} 6+\mathrm{OH}=>\mathrm{C} 2 \mathrm{H} 5+\mathrm{CH} 2 \mathrm{O}$ & $1,00 \mathrm{E}+12$ & 0 & 0 \\
\hline Reactions & Toluene initiation reactions & & & \\
\hline 26 & $\mathrm{C} 6 \mathrm{H} 5 \mathrm{CH} 3+\mathrm{O} 2=\mathrm{C} 6 \mathrm{H} 5 \mathrm{CH} 2+\mathrm{HO} 2$ & $3,00 \mathrm{E}+14$ & 0 & 179706,56 \\
\hline 27 & $\mathrm{C} 6 \mathrm{H} 5 \mathrm{CH} 3+\mathrm{OH}=>\mathrm{C} 6 \mathrm{H} 5 \mathrm{CH} 2+\mathrm{H} 2 \mathrm{O}$ & $5,27 \mathrm{E}+13$ & 0 & 10796,94 \\
\hline 28 & $\mathrm{C} 6 \mathrm{H} 5 \mathrm{CH} 2+\mathrm{HO} 2=>\mathrm{C} 6 \mathrm{H} 5 \mathrm{CHO}+\mathrm{H}+\mathrm{OH}$ & $5,00 \mathrm{E}+12$ & 0 & 0 \\
\hline 29 & $\mathrm{C} 6 \mathrm{H} 5 \mathrm{CHO}+\mathrm{OH}=>\mathrm{C} 6 \mathrm{H} 5 \mathrm{CO}+\mathrm{H} 2 \mathrm{O}$ & $2,25 \mathrm{E}+10$ & 1,18 & $-1868,46$ \\
\hline 30 & $\mathrm{C} 6 \mathrm{H} 5 \mathrm{CO}=>\mathrm{C} 6 \mathrm{H} 5+\mathrm{CO}$ & $3,98 \mathrm{E}+14$ & 0 & 122892 \\
\hline 31 & $\mathrm{C} 6 \mathrm{H} 5+\mathrm{O} 2=>\mathrm{C} 6 \mathrm{H} 5 \mathrm{O}+\mathrm{O}$ & $2,60 \mathrm{E}+13$ & 0 & 25581,6 \\
\hline 32 & $\mathrm{C} 6 \mathrm{H} 5 \mathrm{O}=>\mathrm{CO}+\mathrm{C} 5 \mathrm{H} 5$ & $3,76 \mathrm{E}+54$ & $-12,06$ & 310574 \\
\hline 33 & $\mathrm{C} 5 \mathrm{H} 5+\mathrm{O} 2=>\mathrm{C} 5 \mathrm{H} 4 \mathrm{O}+\mathrm{OH}$ & $1,80 \mathrm{E}+12$ & 0,08 & 75240 \\
\hline 34 & $\mathrm{C} 5 \mathrm{H} 4 \mathrm{O}+\mathrm{O}+2 \mathrm{O} 2=>3 \mathrm{CO}+2 \mathrm{HCO}+\mathrm{H} 2 \mathrm{O}$ & $3,60 \mathrm{E}+16$ & 1,45 & $-3586,44$ \\
\hline Reactions & C2 reactions & & & \\
\hline 35 & $\mathrm{C} 2 \mathrm{H} 5+\mathrm{O} 2=>\mathrm{C} 2 \mathrm{H} 4+\mathrm{HO} 2$ & $2,00 \mathrm{E}+10$ & 0 & -9196 \\
\hline 36 & $\mathrm{C} 2 \mathrm{H} 4+\mathrm{OH}=>\mathrm{CH} 2 \mathrm{O}+\mathrm{CH} 3$ & $6,00 \mathrm{E}+13$ & 0 & 4012,8 \\
\hline 37 & $\mathrm{C} 2 \mathrm{H} 4+\mathrm{H}=>\mathrm{C} 2 \mathrm{H} 3+\mathrm{H} 2$ & $1,51 \mathrm{E}+07$ & 2 & 25080 \\
\hline 38 & $\mathrm{C} 2 \mathrm{H} 3+\mathrm{O} 2=>\mathrm{CH} 2 \mathrm{O}+\mathrm{HCO}$ & $3,98 \mathrm{E}+12$ & 0 & -1045 \\
\hline 39 & $\mathrm{CH} 3 \mathrm{CHO}+\mathrm{OH}+\mathrm{M}=>\mathrm{CH} 3+\mathrm{CO}+\mathrm{M}+\mathrm{H} 2 \mathrm{O}$ & $1,80 \mathrm{E}+17$ & 0 & 60192 \\
\hline Reactions & C1 reactions & & & \\
\hline 40 & $\mathrm{CH} 3+\mathrm{HO} 2=>\mathrm{CH} 3 \mathrm{O}+\mathrm{OH}$ & $4,30 \mathrm{E}+13$ & 0 & 0 \\
\hline
\end{tabular}




\begin{tabular}{|c|c|c|c|c|c|}
\hline 41 & \multicolumn{2}{|c|}{$\mathrm{CH} 3 \mathrm{O}(+\mathrm{M})=\mathrm{CH} 2 \mathrm{O}+\mathrm{H}(+\mathrm{M})$} & $2,00 \mathrm{E}+13$ & 0 & 114615,6 \\
\hline & \multicolumn{2}{|c|}{ Low pressure limit } & $2,34 \mathrm{E}+25$ & $-2,7$ & 127908 \\
\hline 42 & \multicolumn{2}{|c|}{$\mathrm{CH} 2 \mathrm{O}+\mathrm{OH}+\mathrm{O} 2=>\mathrm{H} 2 \mathrm{O}+\mathrm{HO} 2+\mathrm{CO}$} & $6,69 \mathrm{E}+14$ & 1,18 & $-1868,46$ \\
\hline 43 & \multicolumn{2}{|c|}{$\mathrm{CH} 2 \mathrm{O}+\mathrm{O} 2+\mathrm{M}=>\mathrm{H}+\mathrm{CO}+\mathrm{M}+\mathrm{HO} 2$} & $6,20 \mathrm{E}+16$ & 0 & 154660 \\
\hline 44 & \multicolumn{2}{|c|}{$\mathrm{CH} 2 \mathrm{O}+\mathrm{HO} 2=>\mathrm{HCO}+\mathrm{H} 2 \mathrm{O} 2$} & $2,17 \mathrm{E}+11$ & 0 & 33440 \\
\hline 45 & \multicolumn{2}{|c|}{$\mathrm{HCO}+\mathrm{O} 2=>\mathrm{CO}+\mathrm{HO} 2$} & $3,98 \mathrm{E}+12$ & 0 & 0 \\
\hline 46 & \multicolumn{2}{|c|}{$\mathrm{HCO}+\mathrm{M}=\mathrm{H}+\mathrm{CO}+\mathrm{M}$} & $2,50 \mathrm{E}+14$ & 0 & 70232,36 \\
\hline 47 & \multicolumn{2}{|c|}{$\mathrm{CO}+\mathrm{HO} 2=>\mathrm{CO} 2+\mathrm{OH}$} & $1,51 \mathrm{E}+14$ & 0 & 98857 \\
\hline 48 & \multicolumn{2}{|c|}{$\mathrm{CO}+\mathrm{O}=\mathrm{CO} 2$} & $1,80 \mathrm{E}+10$ & 0 & 10190,84 \\
\hline 49 & \multicolumn{2}{|c|}{$\mathrm{CO}+\mathrm{O}+\mathrm{M}=\mathrm{CO} 2+\mathrm{M}$} & $5,89 \mathrm{E}+15$ & 0 & 17138 \\
\hline 50 & \multicolumn{2}{|c|}{$\mathrm{CO}+\mathrm{OH}=\mathrm{CO} 2+\mathrm{H}$} & $3,09 \mathrm{E}+11$ & 0 & 3072,3 \\
\hline 51 & \multicolumn{2}{|c|}{$\mathrm{CO} 2+\mathrm{O}=\mathrm{CO}+\mathrm{O} 2$} & $2,75 \mathrm{E}+12$ & 0 & 183209,4 \\
\hline & \multicolumn{2}{|c|}{ Reverse reaction } & $3,25 \mathrm{E}+11$ & 0 & 153280,6 \\
\hline Reactions & \multicolumn{2}{|c|}{$\mathrm{O} / \mathrm{H}$ reactions } & & & \\
\hline 52 & \multicolumn{2}{|c|}{$\mathrm{HO} 2+\mathrm{HO} 2=\mathrm{H} 2 \mathrm{O} 2+\mathrm{O} 2$} & $3,22 \mathrm{E}+15$ & 0 & $-6809,22$ \\
\hline 53 & \multicolumn{2}{|c|}{$\mathrm{H} 2+\mathrm{O}=>\mathrm{H}+\mathrm{OH}$} & $1,82 \mathrm{E}+10$ & 1 & 37202 \\
\hline 54 & \multicolumn{2}{|c|}{$\mathrm{H} 2 \mathrm{O} 2+\mathrm{OH}=\mathrm{H} 2 \mathrm{O}+\mathrm{HO} 2$} & $1,00 \mathrm{E}+13$ & 0 & 7524 \\
\hline & \multicolumn{2}{|c|}{ Reverse reaction } & $2,03 \mathrm{E}+13$ & 0 & 145798,4 \\
\hline 55 & \multicolumn{2}{|c|}{$\mathrm{H} 2 \mathrm{O}+\mathrm{M}=\mathrm{H}+\mathrm{OH}+\mathrm{M}$} & $2,19 \mathrm{E}+16$ & 0 & 438900 \\
\hline & \multicolumn{2}{|c|}{ Enhancement factors: } & -- & -- & -- \\
\hline & $\mathrm{H} 2 \mathrm{O}$ & 21 & -- & -- & -- \\
\hline & $\mathrm{CO}$ & 2,0 & -- & -- & -- \\
\hline & $\mathrm{H} 2$ & 3,3 & -- & -- & -- \\
\hline 56 & $\mathrm{H}+\mathrm{O}$ & & $2,60 \mathrm{E}+19$ & $-1,24$ & 0 \\
\hline 57 & $\mathrm{H}+\mathrm{O}$ & & $2,07 \mathrm{E}+18$ & $-1,69$ & 3720,2 \\
\hline 58 & $\mathrm{OH}+$ & & $1,91 \mathrm{E}+16$ & -1 & 0 \\
\hline 59 & $\mathrm{H}+\mathrm{O}$ & & $2,10 \mathrm{E}+15$ & $-0,3$ & 84436 \\
\hline 60 & $\mathrm{OH}+$ & & $1,50 \mathrm{E}+09$ & 1,14 & 415,492 \\
\hline 61 & $\mathrm{OH}+$ & & $1,00 \mathrm{E}+25$ & $-5,452$ & 12832,6 \\
\hline 62 & $\mathrm{OH}+$ & & $7,60 \mathrm{E}+13$ & $-0,37$ & -8151 \\
\hline & Low & & $4,30 \mathrm{E}+18$ & $-0,9$ & -7106 \\
\hline & TRO & $346 ; 94 ; 1756 ; 5182$ & -- & -- & -- \\
\hline & Enha & & -- & -- & -- \\
\hline & $\mathrm{H} 2$ & 2,0 & -- & -- & -- \\
\hline & $\mathrm{H} 2 \mathrm{O}$ & 6,0 & -- & -- & -- \\
\hline & $\mathrm{CH} 4$ & 2,0 & -- & -- & -- \\
\hline & $\mathrm{CO}$ & 1,5 & -- & -- & -- \\
\hline & $\mathrm{CO} 2$ & 2,0 & -- & -- & -- \\
\hline & $\mathrm{N} 2$ & 0,7 & -- & -- & -- \\
\hline Reactions & NO-s & tion reactions & & & \\
\hline 63 & $\mathrm{~N}+\mathrm{N}$ & & $3,500 \mathrm{E}+13$ & 0,0 & 1379 \\
\hline 64 & $\mathrm{~N}+\mathrm{O}$ & & $2,650 \mathrm{E}+12$ & 0,0 & 26752 \\
\hline 65 & $\mathrm{~N}+\mathrm{O}$ & & $7,333 \mathrm{E}+13$ & 0,0 & 4682 \\
\hline 66 & $\mathrm{NO}+$ & & $2,100 \mathrm{E}+12$ & 0,00 & -2006 \\
\hline 67 & $\mathrm{NO}+$ & & $5,100 \mathrm{E}+23$ & $-2,31$ & -284 \\
\hline 68 & $\mathrm{NO} 2$ & & $1,000 \mathrm{E}+14$ & 0,00 & 1513 \\
\hline 69 & NO2 & & $6,300 \mathrm{E}+08$ & 1,25 & 20900 \\
\hline 70 & $\mathrm{HON}$ & & $1,26 \mathrm{E}+10$ & 1,00 & 2383 \\
\hline 71 & $\mathrm{CH} 2$ & DNO & $8,00 \mathrm{E}+02$ & 2,77 & 57391 \\
\hline 72 & $\mathrm{CH} 3$ & & $1,51 \mathrm{E}+13$ & 0,0 & 0,0 \\
\hline 73 & $\mathrm{CH} 3 \mathrm{C}$ & HONO & $6,02 \mathrm{E}+12$ & 0,0 & 9551 \\
\hline 74 & $\mathrm{CH} 3 \mathrm{C}$ & $\mathrm{NO} 2$ & $5,50 \mathrm{E}+11$ & 0,00 & -4983 \\
\hline 75 & $\mathrm{C} 2 \mathrm{H}^{\mathrm{L}}$ & & $1,00 \mathrm{E}+13$ & 0,0 & 0,0 \\
\hline
\end{tabular}




\begin{tabular}{|c|l|c|c|c|}
\hline 76 & $\mathrm{C} 2 \mathrm{H} 5 \mathrm{O}+\mathrm{NO} 2=\mathrm{CH} 3 \mathrm{CHO}+\mathrm{HONO}$ & $4,00 \mathrm{E}+11$ & 0,0 & 0,0 \\
\hline 77 & $\mathrm{C} 2 \mathrm{H} 5 \mathrm{O} 2+\mathrm{NO}=\mathrm{C} 2 \mathrm{H} 5 \mathrm{O}+\mathrm{NO} 2$ & $3,00 \mathrm{E}+12$ & 0,0 & -1496 \\
\hline 78 & $\mathrm{C} 7 \mathrm{H} 15 \mathrm{O} 2+\mathrm{NO}=\mathrm{C} 7 \mathrm{H} 15 \mathrm{O}+\mathrm{NO} 2$ & $1,630 \mathrm{E}+14$ & 0,0 & -2989 \\
\hline 79 & $\mathrm{C} 7 \mathrm{H} 15+\mathrm{NO} 2=\mathrm{C} 7 \mathrm{H} 15 \mathrm{O}+\mathrm{NO}$ & $1,510 \mathrm{E}+13$ & 0,0 & 0,0 \\
\hline 80 & $\mathrm{C} 8 \mathrm{H} 17 \mathrm{O} 2+\mathrm{NO}=\mathrm{C} 8 \mathrm{H} 17 \mathrm{O}+\mathrm{NO} 2$ & $2,590 \mathrm{E}+12$ & 0,0 & 0,0 \\
\hline 81 & $\mathrm{C} 8 \mathrm{H} 17+\mathrm{NO} 2=\mathrm{C} 8 \mathrm{H} 17 \mathrm{O}+\mathrm{NO}$ & $1,5 \mathrm{E}+13$ & 0,0 & 0,0 \\
\hline 82 & $\mathrm{C} 6 \mathrm{H} 5 \mathrm{CH} 2 \mathrm{OO}+\mathrm{NO}=\mathrm{C} 6 \mathrm{H} 5 \mathrm{CH} 2 \mathrm{O}+\mathrm{NO} 2$ & $1,630 \mathrm{e}+14$ & 0,0 & -2989 \\
\hline 83 & $\mathrm{C} 6 \mathrm{H} 5 \mathrm{CH} 2+\mathrm{NO} 2=\mathrm{C} 6 \mathrm{H} 5 \mathrm{CH} 2 \mathrm{O}+\mathrm{NO}$ & $1,510 \mathrm{e}+13$ & 0,0 & 0,0 \\
\hline
\end{tabular}


Table 2: Reaction rates of the reaction between $\mathrm{OH}$ and respectively iso-octane, iso-butene and propene as a function of the addition of $\mathrm{NO}$ at an inlet temperature of $70{ }^{\circ} \mathrm{C}$, an equivalence ratio of 0.6 , a compression ratio of 14 and a dilution factor of $14 \mathrm{vol} \%$ for the fuel $11 \mathrm{vol} \% \mathrm{n}$-heptane, $59 \mathrm{vol} \%$ iso-octane and $30 \mathrm{vol} \%$ toluene

\begin{tabular}{|c|l|c|c|c|}
\hline$\#$ & \multicolumn{1}{|c|}{ Reaction } & $0 \mathrm{ppm} \mathrm{NO}$ & $50 \mathrm{ppm} \mathrm{NO}$ & $300 \mathrm{ppm} \mathrm{NO}$ \\
\cline { 3 - 5 } & & \multicolumn{3}{|c|}{$\left[\mathbf{m o l e}^{*} \mathbf{c m}^{-3} * \mathbf{s}^{-1}\right]$} \\
\hline 12 & $\mathrm{IC} 8 \mathrm{H} 18+\mathrm{OH} \rightarrow \mathrm{C} 8 \mathrm{H} 17+\mathrm{H} 2 \mathrm{O}$ & $1.04 * 10^{-3}$ & $1.33^{*} 10^{-3}$ & $8.19^{*} 10^{-4}$ \\
\hline 23 & $\mathrm{IC} 4 \mathrm{H} 8+\mathrm{OH} \rightarrow \mathrm{IC} 3 \mathrm{H} 7+\mathrm{CH} 2 \mathrm{O}$ & $3.99 * 10^{-3}$ & $5.41^{*} 10^{-3}$ & $1.61 * 10^{-4}$ \\
\hline 25 & $\mathrm{C} 3 \mathrm{H} 6+\mathrm{OH} \rightarrow \mathrm{C} 2 \mathrm{H} 5+\mathrm{CH} 2 \mathrm{O}$ & $3.07 * 10^{-3}$ & $5.06^{*} 10^{-3}$ & $5.99 * 10^{-5}$ \\
\hline
\end{tabular}




\section{Figure captions}

Figure 1: Experimental set-up of the HCCI engine and the installation, representing the air, EGR and fuel flows as well as the measurements

Figure 2: Ignition delays as a function of the dilution factor (for respectively $\mathrm{N}_{2}$ and $\mathrm{CO}_{2}$ ) at equivalence ratios of respectively 0.32 and 0.39 at an inlet temperature of $70{ }^{\circ} \mathrm{C}$ and a compression ratio of 10.2 with the fuel PRF40

Figure 3: Heat release ratio of the final ignition $\left(A_{f}\right)$ and the cool flame $\left(A_{c}\right)$ as a function of the dilution factor (for $\mathrm{N}_{2}$ ) at an inlet temperature of $70{ }^{\circ} \mathrm{C}$, a compression ratio of 10,2 , equivalence ratios of 0.32 and 0.41 and using " 60 vol\% n-heptane and 40 vol\% iso-octane as the fuel

Figure 4: Relative total heat release (with respect to the total heat release at no dilution) as a function of the dilution factor (for $\mathrm{N}_{2}$ ) at an inlet temperature of $70{ }^{\circ} \mathrm{C}$, a compression ratio of 10.2, equivalence ratios of 0.32 and 0.41 and using " 60 vol\% n-heptane and 40 vol\% isooctane as the fuel

Figure 5: Pressure profiles as a function of the addition of $\mathrm{CO}$ to the inlet mixture at an inlet temperature of $70{ }^{\circ} \mathrm{C}$, an equivalence ratio of 0.3 and a compression ratio of 10.2 for the fuel n-heptane, calculated by the surrogate mechanism

Figure 6: Ignition delays as a function of the NO addition in the inlet mixture at different equivalence ratios, an inlet temperature of $70^{\circ} \mathrm{C}$, a compression ratio of 10.2 , an EGR ratio of 23 vol $\%$ with the fuel " 60 vol\% $\%$-heptane and 40 vol\% iso-octane"

Figure 7: Heat release as a function of the added percentage NO in the inlet mixture at an inlet temperature of $70{ }^{\circ} \mathrm{C}$, an equivalence ratio of 0.29 , a compression ratio of 10.2 and a mixture of 60 vol\% n-heptane and 40 vol\% iso-octane as the fuel, the dilution by $\mathrm{N}_{2}$ is 23 vol\% 
Figure 8: Heat release as a function of the added percentage NO in the inlet mixture at an inlet temperature of $70{ }^{\circ} \mathrm{C}$, an equivalence ratio of 0.29 , a compression ratio of 10.2 and $\mathrm{n}$ heptane as the fuel; the dilution by $\mathrm{N}_{2}$ is $23 \mathrm{vol} \%$

Figure 9: Normalized $\mathrm{OH}$ concentrations at the cool flame for both n-heptane and PRF40 at a compression ratio of 10.2 , an equivalence ratio of 0.35 and an inlet temperature of $70{ }^{\circ} \mathrm{C}$, using the combined surrogate-NO mechanism [19]

Figure 10: The heat release ratio of the final ignition and the cool flame (with respect to 0 ppmv NO addition) as a function of the addition of $\mathrm{NO}$ at an inlet temperature of $70{ }^{\circ} \mathrm{C}$, a compression ratio of 10.2 , for two equivalence ratios of 0.29 and 0.41 and " $60 \mathrm{vol} \% \mathrm{n}$ heptane / 40 vol\% iso-octane" as the fuel

Figure 11: The total heat release (with respect to 0 ppmv NO addition) as a function of the addition of $\mathrm{NO}$ at an inlet temperature of $70{ }^{\circ} \mathrm{C}$, a compression ratio of 10.2 , for two equivalence ratios of 0.29 and 0.41 and "60 vol\% n-heptane / 40 vol\% iso-octane" as the fuel

Figure 12: Ignition delays as a function of the addition of $\mathrm{CH}_{2} \mathrm{O}$ at the equivalence ratios 0.30 and 0.39 , an inlet temperature of $70{ }^{\circ} \mathrm{C}$ and a compression ratio of 10.2 with the fuel "60 vol\% n-heptane and 40 vol\% iso-octane"

Figure 13: Comparison of the $\mathrm{OH}$ concentration influenced by the addition of $\mathrm{CH}_{2} \mathrm{O}$ at an inlet temperature of $70^{\circ} \mathrm{C}$, a compression ratio of 10.2 and an equivalence ratio of 0.4 using n-heptane as the fuel

Figure 14: The relative total heat release ratio (with respect to $0 \mathrm{ppmv}$ formaldehyde addition) as a function of the addition of $\mathrm{CH}_{2} \mathrm{O}$ at an inlet temperature of $70{ }^{\circ} \mathrm{C}$, a compression ratio of 10.2 and an equivalence ratio of 0.30 and " 60 vol\% n-heptane / 40 vol\% iso-octane" as the fuel

Figure 15: The heat release ratio of the final ignition and the cool flame (with respect to 0 ppmv formaldehyde addition) as a function of the addition of $\mathrm{CH}_{2} \mathrm{O}$ at an inlet temperature of 
$70{ }^{\circ} \mathrm{C}$, a compression ratio of 10.2 and equivalence ratios of 0.30 and 0.41 with " $60 \mathrm{vol} \% \mathrm{n}$ heptane / $40 \mathrm{vol} \%$ iso-octane" as the fuel 